\title{
MODELLING MORTGAGE INSURANCE CLAIMS EXPERIENCE: A CASE STUDY
}

\author{
By GREg TAYLOR \\ December 1991 \\ Revised June 1993 \\ A Coopers \& Lybrand research report
}

\begin{abstract}
Mortgage insurance indemnifies a mortage lender against loss on default by the borrower. The sequence of events leading to a claim under this type of insurance is relatively complex, depending not only on the credit worthiness of the borrower but also on a number of external economic factors.

Prominent among these external factors are the loan to valuation ratio of the insured loan, the disposable income of the borrower, and movements in property values. A broad theoretical model of the functional dependencies of claim frequency and average claim size on these variables is established in Sections 6 and 7. Section 8 fits these models, extended by other "internal" variables such as the geographic location of the mortgaged property, to a real data set.

Section 9 compares the fitted model with the data, and finds an acceptable fit despite extreme fluctuations in the claims experience recorded in the data set.
\end{abstract}

\section{KEYWORDS}

Mortgage insurance; housing price index; loan to valuation ratio; regression.

\section{INTRODUCTION}

Mortgage insurance indemnifies a mortgage lender against loss on default by the borrower. The typical sequence of events leading to the invocation of the indemnity is as follows.

The amount of the mortgage is repayable by a sequence of instalments, perhaps monthly, over a period of some years, up to perhaps 25 or in a few cases more. If a borrower fails to meet one or more of these instalments, arrears collection procedures will be instigated. If it appears that the borrower is experiencing financial difficulties which threaten his capacity to pay the scheduled instalments, the lender's initial response will usually be to attempt rehabilitation of the borrower, possibly by some form of rescheduling of the debt repayment.

In many cases this will render the borrower's difficulties temporary. In other ASTIN BULLETIN, Vol. 24, No. 1, 1994 
less fortunate cases it will become clear that the borrower is quite unable to repay the debt. The lender will then force sale of the mortgaged property, and retain that part of the sale proceeds required to discharge the remaining debt. In the majority of sales, the proceeds will be sufficient for this purpose, but if they are not the mortgage insurance indemnity is invoked to reimburse the lender for the shortfall.

It is an elementary observation that inflation of property values reduces the call on mortgage insurance; the proceeds of property sales cover a greater proportion of the corresponding debts. It is also clear from the above description that a loan needs to go through several stages (healthy $\rightarrow$ in arrear $\rightarrow$ property under management $\rightarrow$ sale of property) before a mortgage insurance claim arises, and each of these stages involves some delay. As will be discussed in Section 3, each of them also depends on its own specific economic factors.

For these reasons, the underlying process generating mortgage insurance claims is complex and dependent on several variables which are exogenous to the insurance portfolio. Consequently, mortgage insurance run-off arrays, whether in terms of numbers or amounts of claims, exhibit very different characteristics from those of other lines of business. A striking example of this is given in Section 2.

These different characteristics necessitate rather different modelling techniques. The purpose of the present paper is to illustrate these techniques by means of a case study. Since this study is specific to a particular portfolio, it cannot be claimed that the modelling techniques illustrated are generally applicable. It is hoped, however, that they are fairly generally indicative of the type of modelling which needs to be attempted.

\section{NUMERICAL EXAMPLE: PRELIMINARY DISCUSSION}

The following data are given as an indication of the difficulties likely to arise if a mortgage insurance portfolio is subjected to conventional run-off analysis. More detail of the data on which this paper is based appears in Appendices E and G.

\begin{tabular}{|c|c|c|c|c|c|c|c|c|c|c|c|}
\hline \multirow{2}{*}{$\begin{array}{c}\text { Year of } \\
\text { loan } \\
\text { advance }\end{array}$} & \multicolumn{11}{|c|}{ Number of claims, per 10,000 loan advances, emerging in development year (a) } \\
\hline & 0 & 1 & 2 & 3 & 4 & 5 & 6 & 7 & 8 & 9 & 10 \\
\hline 1980 & & & & & 30 & 18 & 6 & 0 & 0 & 0 & 6 \\
\hline 1981 & & & & 116 & 42 & 31 & 5 & 0 & 0 & 0 & \\
\hline 1982 & & & 54 & 27 & 45 & 36 & 13 & 13 & 4 & & \\
\hline 1983 & & 25 & 20 & 20 & 23 & 9 & 0 & 3 & & & \\
\hline 1984 & 0 & 13 & 24 & 55 & 35 & 5 & 0 & & & & \\
\hline 1985 & 1 & 21 & 134 & 68 & 15 & 6 & & & & & \\
\hline 1986 & 0 & 17 & 30 & 4 & 2 & & & & & & \\
\hline 1987 & 3 & 1 & 0 & 2 & & & & & & & \\
\hline 1988 & 0 & 0 & 5 & & & & & & & & \\
\hline 1989 & 0 & 0 & & & & & & & & & \\
\hline 1990 & 0 & & & & & & & & & & \\
\hline
\end{tabular}

(a) Development year is defined as year of emergence of claim minus year of loan advance. 
Let the term relative claims frequency denote the number of claims per 10,000 loan advances. If $C_{i j}$ denotes the relative claim frequency in development year $j$ of year of advance $i$, and $A_{i j}$ denotes the age-to-age factor:

$$
A_{i j}=\sum_{k=0}^{j+1} C_{i k} / \sum_{k=0}^{j} C_{i k^{\prime}}
$$

then the following table of age-to-age factors is obtained.

\begin{tabular}{lccccc}
\hline \hline \multirow{2}{*}{$\begin{array}{c}\text { Year of } \\
\text { loan } \\
\text { advance } i\end{array}$} & 1 & 2 & 3 & 4 & 5 \\
\cline { 2 - 6 } & 2.86 & 2.50 & 1.38 & 1.04 & 1.00 \\
1984 & 7.12 & 1.44 & 1.07 & 1.03 & \\
1985 & 2.71 & 1.08 & 1.05 & & \\
1986 & 1.00 & 1.50 & & & \\
1987 & & & & & \\
\hline
\end{tabular}

The great instability in these ago-to-age factors is evident in the sense of variability within a development year. The basic reason for the instability is clear from the first table. It is the apparent correlation between relative claim frequency and year of emergence of claim, i.e. with the number of the diagonal in the table. Such a data structure suggests application of the separation method (TAYLOR, 1977, 1986), with the model structure:

$$
E\left[C_{i j}\right]=r_{j} \lambda_{i+j}
$$

The separation method yields the following parameter estimates.

\begin{tabular}{rccc}
\hline$j$ & $\hat{r}_{j}$ & $k$ & $\hat{\lambda}_{k}$ \\
\hline 0 & 0.00 & & \\
1 & 0.06 & & \\
2 & 0.20 & & \\
3 & 0.22 & 1984 & 366 \\
4 & 0.14 & 1985 & 167 \\
5 & 0.11 & 1986 & 195 \\
6 & 0.03 & 1987 & 350 \\
7 & 0.03 & 1988 & 196 \\
8 & 0.02 & 1989 & 48 \\
9 & 0.00 & 1990 & 29 \\
10 & 0.20 & & \\
\hline
\end{tabular}

This produces the following comparison between observed and fitted relative claim frequencies. 


\begin{tabular}{|c|c|c|c|c|c|c|c|c|c|c|c|c|c|c|c|c|c|c|c|c|c|c|c|c|c|}
\hline \multirow{2}{*}{$\begin{array}{c}\text { Year of } \\
\text { loan } \\
\text { advance }\end{array}$} & \multicolumn{25}{|c|}{ Observed and fitted (shown in bold type) relative claim frequency in development year } \\
\hline & 0 & & 1 & & 2 & ? & 3 & 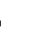 & & 4 & & 5 & & & 6 & & 7 & & 8 & & 9 & & 10 & & tal \\
\hline 1980 & & & & & & & & & & 52 & & & & & & & & & & 3 & 0 & 6 & 6 & 60 & 94 \\
\hline 1981 & & & & & & & 116 & 79 & 42 & 24 & 3 & 1 & 21 & 5 & 11 & & 0 & 5 & & 1 & & & & 195 & 140 \\
\hline 1982 & & & & & & & 27 & 36 & 45 & 28 & 3 & 6 & 38 & 13 & 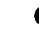 & & & 1 & & & & & & 193 & 181 \\
\hline 1983 & & & 5 & 21 & 20 & 33 & 20 & 42 & 23 & 50 & & 9 & 21 & 0 & & & 3 & & & & & & & 101 & 169 \\
\hline 1984 & 0 & 1 & & 9 & 24 & 38 & 55 & 76 & 35 & 28 & & & 5 & & & & & & & & & & & 131 & 159 \\
\hline 1985 & 1 & 2 & 11 & 11 & 134 & 69 & 68 & 42 & 15 & 7 & & & & & & & & & & & & & & 245 & 133 \\
\hline 1986 & 0 & & 7 & 20 & 30 & 38 & 4 & 10 & & & & & & & & & & & & & & & & 53 & 73 \\
\hline 1987 & 3 & & 1 & 11 & & 9 & & & & & & & & & & & & & & & & & & 6 & 28 \\
\hline 1988 & 0 & & & 3 & 5 & & & & & & & & & & & & & & & & & & & 5 & 9 \\
\hline 1989 & 0 & & & 2 & & & & & & & & & & & & & & & & & & & & 0 & 2 \\
\hline 1990 & 0 & & & & & & & & & & & & & & & & & & & & & & & 0 & 0 \\
\hline
\end{tabular}

The table indicates that the separation method achieves a reasonable fit. No formal goodness-of-fit statistics are examined, because this model is later discarded. The difficulty is that, despite the reasonableness of the fit, the sequence of escalation index numbers $\lambda_{k}$ is peculiar by normal standards. Until some explanation of this peculiarity is found, it is impossible to produce any reliable projection of the sequence into future years.

One of the major objectives of subsequent sections of this paper will therefore be to obtain such an explanation. The discussion of this aspect of the modelling problem is taken up in Section 3.

\section{THE PROCESS OF CLAIM OCCURRENCE}

\subsection{Major financial factors}

As pointed out in Section 1, a loan must traverse several stages of financial deterioration before producing a mortgage insurance claim. These stages are subject to different financial influences. Of these separate influences, two are of particular prominence:

(a) the onset of financial difficulties for the borrower; and

(b) in the event of forced sale, the extent to which the sale proceeds repay the outstanding loan.

These two factors are discussed in the following two sub-sections.

\subsection{Onset of borrower's financial difficulties}

Despite its importance in a borrower's budget, the mortgage payment instalment will nevertheless be to some extent a residual item in that budget. It will rank after tax and consumer expenditure on necessities (food, clothing, etc.). In addition, most past loans have been of a type whereby the amount of instalment varies with variations in current day interest rates. 
It appears, therefore, that a reasonable measure of the degree of financial pressure on mortgage borrowers would be provided by an estimate of the average residual income after allowance for tax, consumer expenditure and mortgage instalment. This residual income, called here the home affordability index (HAI), was constructed in the following form:

Home affordability index $=$ average weekly gross household income minus

$\operatorname{tax}$

minus

consumer expenditure

minus

mortgage instalment,

expressed as a percentage of gross income.

A baseline distribution of gross household income over these categories of expenditure was derived from a 1988/89 household expenditure survey (HES) conducted by the Australian Bureau of Statistics. The items of expenditure for this base year were adjusted to other years in various ways, indicated by the following table.

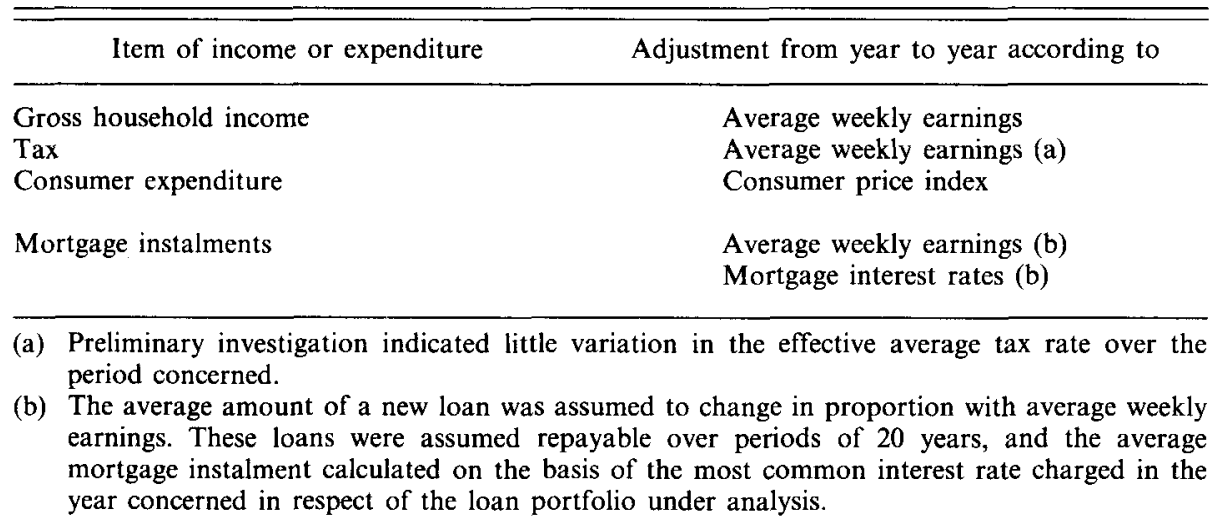

The component time series used in the construction of the HAI (at year end) are set out as Appendix F.

The resulting HAI (at mid-year) is as set out in the following table.

The rather irregular progression of this index is seen in Appendix $F$ to derive from quite reasonable component indexes. Each of these components may be projected over future years, producing a rationally based projection of HAI. This situation may be contrasted with that which arises on application of "black box" estimates of past claims escalation, as in Section 2, and in which no guidance as to future escalation is available. 


\begin{tabular}{cc}
\hline \hline Year & Home affordability index \\
\hline 1979 & 100.0 \\
1980 & 104.8 \\
1981 & 111.9 \\
1982 & 101.7 \\
1983 & 104.1 \\
1984 & 128.9 \\
1985 & 128.3 \\
1986 & 101.7 \\
1987 & 87.4 \\
1988 & 90.6 \\
1989 & 81.5 \\
1990 & 81.2 \\
\hline
\end{tabular}

\subsection{Recovery of outstanding loan on forced sale}

The HAI of Section 3.2 provides an indication of the likelihood that an individual borrower will experience financial difficulty in a particular year. However, such difficulty, while a necessary condition, is not sufficient for the emergence of a mortgage insurance claim. It is quite possible the borrower's difficulties are such as to force sale of the property, but that property values will be sufficient for the entirety of the outstanding loan amount to be recovered by the lender.

Whether or not this is the case will depend mainly on movements in property values between the date of advance of the loan and the date of the forced sale. In Sydney these movements may be estimated by reference to the Housing Price Index (HPI) computed and published by Residex Pty Limited. The following table was derived from that index with slight modification.

\begin{tabular}{cc}
\hline $\begin{array}{c}\text { Year ended } \\
\text { 30 June }\end{array}$ & $\begin{array}{c}\text { Housing price index } \\
\text { (Sydney) at mid-year } \\
(30 / 6 / 79=100)\end{array}$ \\
\hline 1980 & 115.3 \\
1981 & 145.1 \\
1982 & 158.6 \\
1983 & 158.4 \\
1984 & 168.2 \\
1985 & 177.2 \\
1986 & 182.4 \\
1987 & 191.5 \\
1988 & 245.8 \\
1989 & 363.5 \\
1990 & 430.7 \\
\hline
\end{tabular}


Evidently, the greater the increase in value of properties generally, the less the chance that forced sale of a particular property will lead to a loss to the mortgage lender.

\subsection{Lags in claims process}

While movements in the HAI (Section 3.2) and HPI (Section 3.3) have been identified as major variables in the frequency of mortgage insurance claims, it is to be expected that there will be a lag between cause and effect in each case.

Information from the company operating the mortgage insurance portfolio discussed in this paper was that, broadly:

(a) the average period between mortgage instalments falling in arrears and the property being taken under management (if indeed this latter occurred) was about 6 months; and

(b) the average period between taking a property under management and effecting its sale was also about 6 months.

On the basis of this information, it might be reasonable to expect lags of:

(a) 12 months between movements in the HAI and the consequent movement in claim frequency; and

(b) 6 months between a movement in the HPI and its consequent movement in claim frequency.

Thus, it has been assumed in subsequent modelling that a claim frequency experienced during year $t$ is dependent upon:

(a) the value of the home affordability index at the middle of year $t-1$; and

(b) the value of the HPI at the end of year $t-1$.

Examination of alternatives suggested that this choice of lags provided about the best fit of model to data. Further detail on the incorporation of the HAI and HPI in the model is given in Section 6.2.

\section{DATA}

\subsection{Variables affecting claims experience}

Section 3 identified the HAI and HPI as likely to be major explanatory variables of claim frequency. Other variables in this category include:

(a) the proportion of the original property value advanced by way of mortgage, i.e. the loan to valuation ratio (LVR);

(b) the geographic area of the mortgaged property (described in more detail in Section 4.2);

(c) the agreed term of the mortgage loan; 
(d) the type of property mortgaged (e.g. new house, old unit, land only, etc.);

(e) the financial type of the loan (e.g. reducible loan with variable interest, interest only instalments with fixed interest rate, etc.).

In addition, it is likely that claims experience will vary with development year, even in the absence of movements in the HAI and HPI. This would reflect a process of natural selection operating on each year's mortgage advances, whereby the poorest risks succumb to financial pressures relatively early, and the remainder survive the mortgage term.

It is clear that the major variable affecting claim size will be the size of the original loan. In addition, the explanatory variables (a) to (e) of claim frequency potentially affect claim size also.

\subsection{Form of data}

As the tables of Section 2 indicate, claims experience relates to the period 1984 to 1990 . In fact, the 1984 experience covers only 7 months of that year.

Data supplied in respect of these claims consisted of a claim by claim tabulation, recording in each case the relevant variables identified in Section 4.1:

(a) year of advance;

(b) amount of loan;

(c) value of property;

(d) geographic area of property;

(e) term of loan;

(f) type of property;

(g) financial type of loan;

(h) year of emergence of claim.

The tabulated geographic area was the postal code of the property. These codes were grouped into 14 broad urban and rural regions within the states of New South Wales and Australian Capital Territory, as follows:

Metropolitan regions 1 to 5; Canberra (6); Newcastle (7); Wollongong (8); Central Coast (9); North Coast (10); South Coast (11); Blue Mountains (12); Southern Highlands (13); Other (14).

The exposure base for the study consisted of all loans advanced over the years 1980 to 1990 inclusive. These were recorded, loan by loan, according to the variables (a) to (g) listed above as potentially affecting claim frequency.

As the data described above constitute a unit record file, it is not practical to present the full detail here. It is not even practical to tabulate cells of data since there are 1499 exposure cells. However, Appendix G gives a tabulation of exposures and claims according to year of advance and development year. It is to be stressed that, while such a tabulation is interesting, it omits a great deal of the raw data. 


\section{EXPLORATORY DATA ANALYSIS}

\subsection{Claim frequency}

Section 4.1 identified a number of characteristics of individual loans (such as LVR, term of loan, etc.) which might have a bearing on the likelihood of those loans leading to claims. These characteristics will be referred to here as risk variables.

Initially, data concerning claim numbers were analysed according to the risk variables listed in Section 4.1. This provided initial guidance concerning the types of loans which were subject to high or low risk of default.

The results of this analysis are summarized in the following sequence of bar charts.
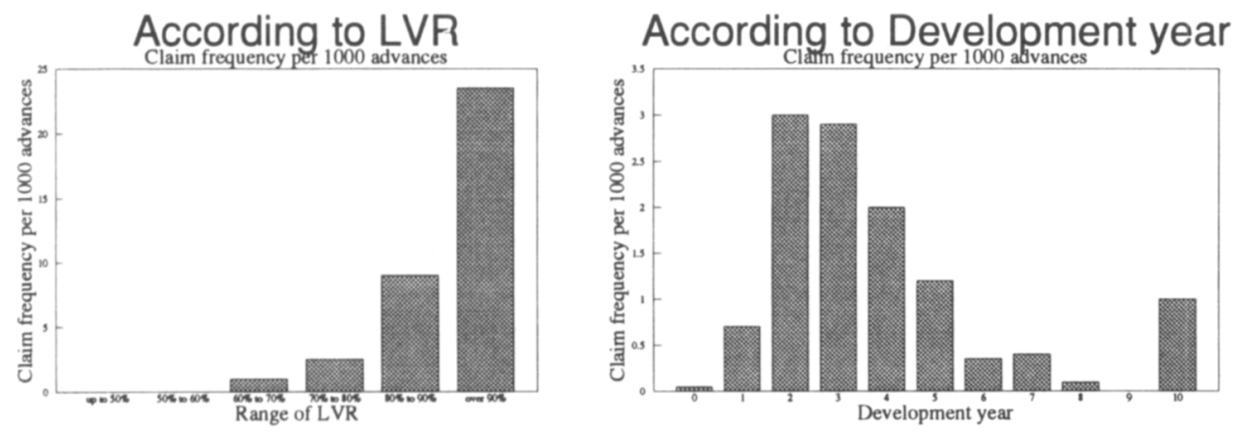

According to Term of loan
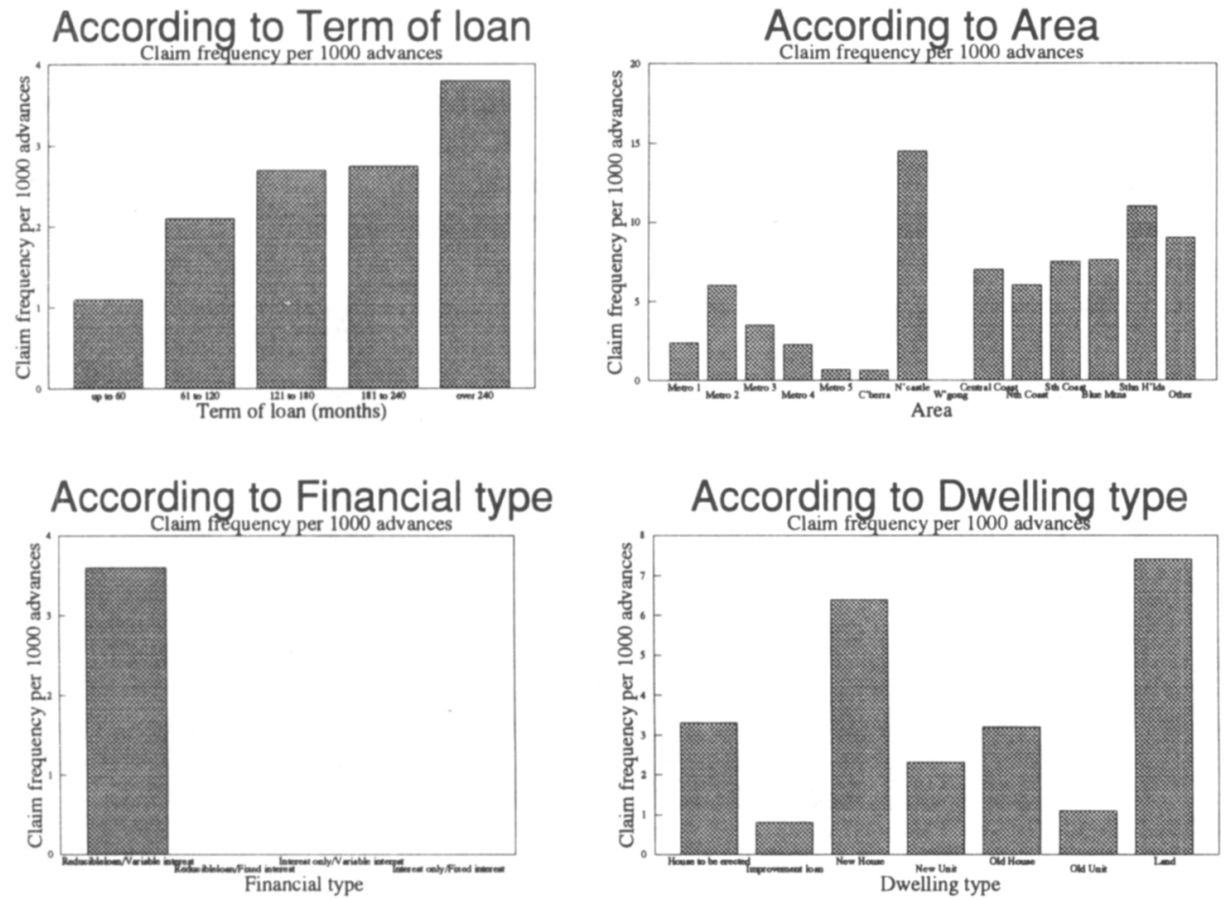
These charts raise the following possibilities:

(a) claim frequency peaks in the second, third and fourth years after the year of advance;

(b) claim frequency increases dramatically with increasing loan to valuation ratio (LVR);

(c) claim frequency increases significantly with increasing term of loan;

(d) certain geographic areas experience conspicuously higher or lower claim frequencies than average;

(e) defaults appear to be confined totally to reducible loans carrying a variable interest rate;

(f) claim frequency appears highest in relation to land, higher in relation to new properties than old, and lowest in relation to improvement loans.

As stated, these are raised as possibilities only, rather than conclusions. Without further analysis, it would be impossible to determine whether all of these variables affect the default risk directly, or some of them are merely correlated with the genuinely operative risk variables.

For example, it might be the case that term of loan has no bearing on default risk, but appears to be relevant because LVR does have such a bearing and long terms are associated with high LVRs.

The question of possible correlation between risk variables is remarked upon further in Section 8.1.

\subsection{Claim size}

Initially, data concerning claim sizes were analysed according to the risk varibles listed in Section 4.1. This provided initial guidance concerning the

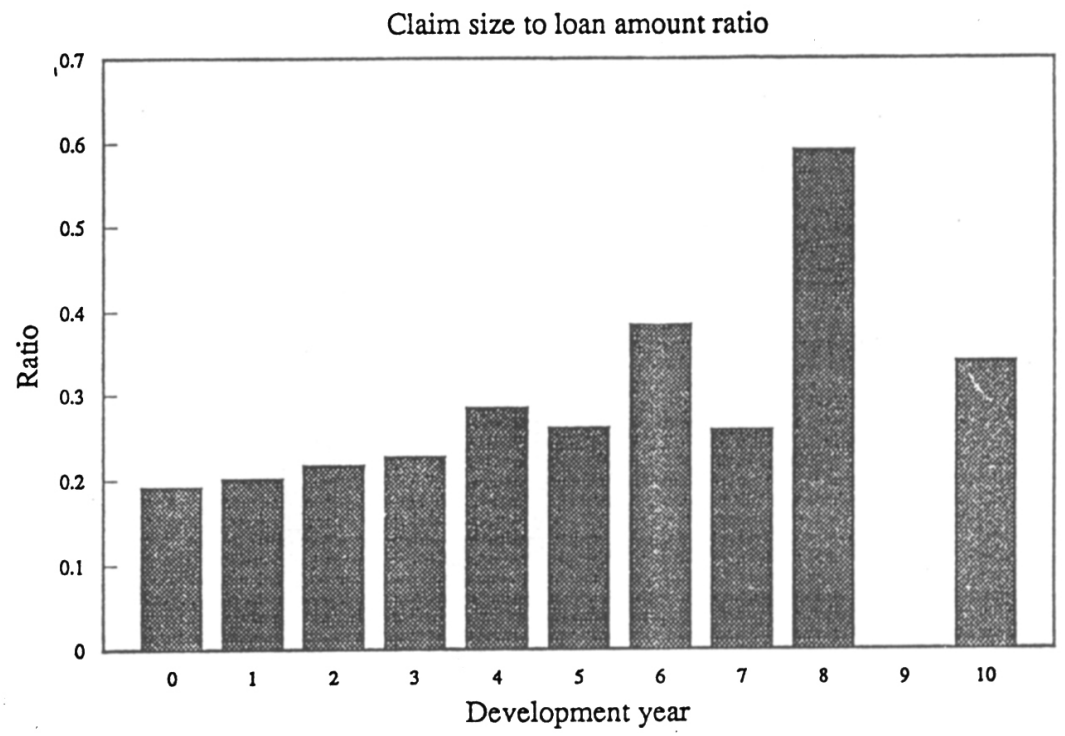


types of loans which led to larger or smaller losses when default occurred. The detailed results of this analysis are set out in Appendix D. The results indicate little variation in claim size with any of the risk variables except development year. The variation of claim size with development year is graphed in the preceding chart.

The chart suggests that the greater the time elapsed between advance of loan and default, the greater the claim size to loan amount ratio, i.e. the greater the loss on default expressed as a proportion of the original advance. This result is confirmed by formal regression analysis, as described in Section 8.2.

Since growth in property value generally increases with development year, this chart is consistent with the predicted form (7.2) of model.

\section{FORM OF CLAIM FREQUENCY MODEL}

\subsection{General}

In the following the basic units of tabulation of claims data will be referred to as cells. A cell will consist of an item of data associated with a particular combination of year of advance, development year, and any sub-set of the risk variables identified in Section 4.1.

It is reasonable that the total effect of risk variables on claim frequency should be multiplicative, i.e.

expected relative claim frequency $=$ function (development year, HAI, HPI)

$x$

function (risk variables, e.g. LVR, geographic area, etc.).

The form of the first of the two functions on the right will be discussed in Section 6.2. As far as the second function is concerned, a reasonable first approximation would consist of the product of a factor in respect of each of the risk variables present. Equation (6.1) then becomes:

$$
\begin{aligned}
& \text { expected relative claim frequency }=\text { function (development year, HAI, } \\
& \text { HPI) } \\
& \times \\
& \text { factor dependent on LVR } \\
& \times \\
& \text { factor dependent on geographic area } \\
& \times \\
& \text { etc. }
\end{aligned}
$$

Interactions between the factors making up this product could be added if necessary. 
Expected relative claim frequency (per loan advanced) is adjusted by a factor of $7 / 12$ in all cells whose experience relates to 1984. This allows for the fact that the data include only 7 months' claims (Section 4.2).

Some of the risk variables identified in Section 4.1, e.g. financial type of loan, are categorical by nature. Others, e.g. LVR, are continuous by nature. It was convenient for exploratory analysis of the data to convert all variables (i.e. risk variables, not HAI and HPI) to categorical form. Details appear in Section 5.1. The categorical form of data was retained in the final modelling, described in Section 8.1.

\subsection{Dependence on development year and economic variables}

Preliminary analysis (Section 5.1) indicated that relative claim frequency, expressed as a function of development year, was generally consistent with the shape of a Hoerl curve. Appendix B provides a theoretical underpinning of this observation. Consequently, the model adopted for relative claim frequency in the absence of any other effects took the form:

$$
\text { const. } \times(j+1 / 2)^{\alpha} \exp (-c j),
$$

where $j$ represents development year.

The modification of (6.3) by HAI and HPI raises some questions. Consider HAI first.

As noted in Section 3.2, the HAI may be regarded as a measure of the average borrower's residual income after payment of mortgage instalment. An individual borrower will experience difficulties in payment of mortgage instalment if this residual income turns negative. The frequency with which this occurs in the event of movements of HAI will depend on the distribution of individual residual incomes, rather than just the average of this distribution represented by HAI. There is virtually no information available in respect of this distribution.

There is, however, some evidence that individual gross incomes are subject to a Paretian distribution (MANDELBROT, 1960).

If a similar assumption is made about residual incomes after payment of mortgage instalment (i.e. HAI), then Appendix A demonstrates that, to first approximation, logged claim frequency will contain a term linear in $R(i+j)_{l}^{\prime} R(i)$, where $i$ denotes year of advance, $j$ development year, and $R(t)$ the HAI experienced in year $t$. Allowance for the one year lag in the effect of HAI, as discussed in Section 3.4, modifies this term to $R(i+j-1) / R(i)$ ( 1 in the case $j=0$ ).

Because of the approximations leading to this result in Appendix A, an alternative linear term involving

$$
\log [R(i+j-1) / R(i)] \quad \text { for } \quad j \geq 1 ;
$$

or

$$
0, \quad \text { for } \quad j=0 \text {, }
$$


was tried. This latter form produced a slightly better fitting regression than the unlogged ratio, and has been adopted henceforth. In fact, both alternatives produced quite similar results.

Appendix B, particularly (B.10), demonstrates that, under seemingly reasonable assumptions about the accumulation of the amount of mortgage debt on default, and about property values on resale, claim frequency should also contain the following factor involving LVR and HPI:

$$
L^{v}[H(i+j) / H(i)]^{-v}, \quad v \text { const. }>0,
$$

where $L$ denotes LVR and $H(t)$ the HPI experienced in year $t$. In order to accommodate the lag in the effect of HPI discussed in Section 3.4, this last expression should be modified to the following:

$$
L^{v}[H(i+j-1 / 2) / H(i)]^{-v}, \quad j \geq 1 ;
$$

or

$$
L^{v}, \quad j=0,
$$

where $H(t-1 / 2)$ is interpreted a the HPI experienced at the end of year $t-1$.

Note that (6.5) indicates that claim frequency should include the same power of both LVR and HPI. However, this result was derived in Appendix B on the assumption that LVR affected the proportion of principal outstanding at default, but not the risk of default itself. In practice, it is likely that LVR is correlated with the ability of the borrower to meet financial commitments, in which case it intrinsically affects the risk of default. For this reason, (6.5) should be generalized to the following:

$$
L^{\lambda}[H(i+j-1 / 2) / H(i)]^{-v}, \quad j \geq 1 ;
$$

or

$$
L^{\lambda}, \quad j=0 .
$$

Combination of (6.2) to (6.4) and (6.6) yields the following model :

(6.7) expected relative claim frequency in development year $j$ of year advance $i$

$$
\begin{aligned}
= & \text { const. } \times(j+1 / 2)^{\alpha} \exp (-c j) \\
& \times L^{\lambda}[R(i+j-1) / R(i)]^{-p}[H(i+j-1 / 2) / H(i)]^{-v} \\
& \times \text { factor dependent on geographic area } \\
& \times \text { etc. for } j \geq 1,
\end{aligned}
$$

and with the two square bracketed terms removed in the case $j=0$.

Let $\mu(i, j)$ denote the expected relative claim frequency $(6.7)$, and $E(i)$ the number of loans advanced in year $i$. Let $N(i, j)$ denote the number of claims emerging in development year $j$ of year of advance $i$. Then the claim frequency model adopted was:

$$
N(i, j) \sim \text { Poisson }[E(i) \mu(i, j)]
$$


It should be noted that the precise form of dependency of relative claim frequency on LVR and HPI in (6.7) relies upon distributional assumptions made in Appendix B. If these assumptions were varied, the form of (6.7) would change. Consequently, an alternative to (6.7) is considered in Section 8.1, in which the terms involving LVR and HAI are replaced by:

$$
\exp (\lambda L) \exp [-v H(i+j-1 / 2) / H(i)] .
$$

This alternative model turns out to be inferior to (6.7).

\section{FORM OF AVERAGE CLAIM SIZE MODEL}

Appendix $C$ shows that, on the same seemingly reasonable assumptions as in Appendix B (referred to in relation to the development of (6.5)), the average claim size in respect of loans advanced in year $i$ should progress over development years according to the following parametric form:

$$
E[Q(i, j)]=\text { const. } \times H(i+j) / H(i),
$$

where

$Q(i, j)=$ the claim ratio (i.e. ratio of claim size to original loan size) experienced in development year $j$ of year of advance $i$;

$H(t)=$ HPI experienced during year $t$.

One may note the interesting effect whereby average claim size increases with development year even though outstanding principal is decreasing. Clearly this result derives from the assumptions made in Appendices B and C. Different assumptions would lead to a different parametric form in (7.1). However, an examination of the development of Appendix $\mathrm{C}$ indicates that the property of increasing $E[Q(i, j)]$ with $H(i+j)$ derives only from an assumption that the variable $\gamma$ has a decreasing failure rate, where $\gamma=\alpha / \beta$ and

$\alpha=\mathbf{a}$ random variable representing the factor by which outstanding principal has been enlarged after default by arrears of principal and interest and any other costs,

$\beta=$ a random variable representing the factor by which the property value has been reduced by the forced nature of the sale and the associated expenses.

While there is no particular evidence concerning the failure rate of $\gamma$, it is interesting to note that the seemingly reasonable assumption of a Pareto distribution leads to the result (7.1) which is found in Section 8.2 to accord with experience, at least to the extent that the claim ratio trends upward with increasing property factor. However, because the Pareto assumption may be a little too specific, it is reasonable to widen the model (7.1) to the following:

$$
Q(i, j)=a+b H(i+j) / H(i)+\text { error term, }
$$

where approximately 


$$
\text { error term } \sim N\left(0, \sigma^{2}\right) .
$$

The appropriateness of this error term is discussed further in Section 8.2.

\section{FITTING THE MODEL}

\subsection{Claim frequency}

By (6.7) and (6.8),

$$
\begin{aligned}
\log E[N(i, j)]= & \log E(i)+\text { const. }+\alpha \log (j+1 / 2)-c j \\
& +\lambda \log L-p \log [R(i+j-1) / R(i)] \\
& -v \log [H(i+j-1 / 2) / H(i)] \\
& + \text { term dependent on geographic area } \\
& + \text { etc., } j \geq 1,
\end{aligned}
$$

with the two square bracketed terms on the right omitted for the case $j=0$.

\begin{tabular}{|c|c|c|}
\hline \multicolumn{3}{|c|}{ Geographic area } \\
\hline Original coding (a) & First aggregation & Second aggregation \\
\hline $\left.\begin{array}{l}1 \\
4 \\
3 \\
5 \\
6\end{array}\right\}$ & $\left.\begin{array}{ll}\text { Area } & 1 \\
\text { Area } & 3 \\
\text { Area } & 4 \\
\text { Area } & 5\end{array}\right\}$ & AREA 1 \\
\hline 2 & Area 2 & AREA 2 \\
\hline $\left.\begin{array}{l}7 \\
10-12\end{array}\right\}$ & Area 6 & AREA 3 \\
\hline $\left.\begin{array}{l}9 \\
14\end{array}\right\}$ & Area 7 & \\
\hline 13 & Area 9 & \\
\hline 8 & Area 8 & AREA 4 \\
\hline
\end{tabular}
This linear form, subject to the error structure (6.8), was fitted to the data using GLIM (Generalised Linear Interactive Modelling) (Royal Statistical Society, 1987). Various combinations of the potential explanatory variables listed in Section 4.1 were tried, and the main results are reported in the next table but one.

(a) As set out in Section 4.2 . 
The results of the trial regressions are displayed in the following table.

\begin{tabular}{|c|c|c|c|c|c|c|c|}
\hline \multirow{2}{*}{ Variable } & \multicolumn{7}{|c|}{ Coefficient in variable at left (a) in Regression No. } \\
\hline & 1 & 2 & 3 & 4 & 5 & 6 & 7 \\
\hline Regression constant & -9.505 & -12.18 & -10.50 & -9.848 & -12.90 & -5.776 & -5.943 \\
\hline Development year & -1.093 & -1.143 & -1.218 & -1.097 & -1.096 & -1.119 & -0.8536 \\
\hline Log (development year $+1 / 2)$ & 4.908 & 5.066 & 4.558 & 4.906 & 4.903 & 5.076 & 4.505 \\
\hline $\operatorname{LVR}(\mathrm{d})$ & 1.100 & 1.144 & 0.994 & 1.100 & 1.099 & & \\
\hline $\log (\mathbf{L V R})$ & & & & & & 8.93 & 8.413 \\
\hline Log (home affordability factor) (b) & & & & & & & -2.158 \\
\hline Property growth factor (c) & -3.039 & -3.070 & -2.036 & -3.017 & -3.015 & & \\
\hline Log (property growth factor) & & & & & & -4.636 & -5.658 \\
\hline \multicolumn{8}{|l|}{ Indicator variables $(f)$ : } \\
\hline AREA 2 & & & & 0.52 & 0.52 & 0.53 & 0.5131 \\
\hline AREA 3 & & & & 0.87 & 0.87 & 0.87 & 0.8772 \\
\hline AREA 4 & & & & -5.24 & -5.24 & -5.25 & $-7.254^{*}$ \\
\hline Area 2 & 0.60 & & & & & & \\
\hline Area 3 & $0.16^{*}$ & & & & & & \\
\hline Area 4 & $-0.35^{*}$ & & & & & & \\
\hline Area 5 & $-0.26^{*}$ & & & & & & \\
\hline Area 6 & 1.05 & & & & & & \\
\hline Area 7 & 1.15 & & & & & & \\
\hline Area 8 & $-5.33^{*}$ & & & & & & \\
\hline Area 9 & 0.81 & & & & & & \\
\hline $60 \leq$ Term $<120$ months & & $3.74^{*}$ & & & & & \\
\hline $120 \leq$ Term $<180$ months & & $2.95^{*}$ & & & & & \\
\hline $180 \leq$ Term $<240$ months & & $2.00^{*}$ & & & & & \\
\hline $240 \leq$ Term & & $2.74^{*}$ & & & $3.06^{*}$ & & \\
\hline \multicolumn{8}{|l|}{ Dwelling: } \\
\hline Improvements \& increases & & & $1.33^{*}$ & & & & \\
\hline All other than improvements, & & & & & & & \\
\hline increases \& land only & & & $0.64^{*}$ & & & & \\
\hline Dwelling type missing & & & $7.05^{*}$ & & & & \\
\hline Deviance (e) & 854 & 549 & 632 & 611 & 610 & 593 & 527 \\
\hline
\end{tabular}

(a) Dependent variable in regression log (claim frequency), as in (8.1).

An asterisk attached to a coefficient in the table indicates that this coefficient differs from zero by less than 2 standard errors.

(b) The home affordability factor is the ratio of values of HAI appearing in (8.1).

(c) The property growth factor is the ratio of values of HPI appearing in $(8.1)$.

(d) The variable referred to here is in fact

$$
10 \times \text { LVR }-3.5
$$

The variable $\log (\mathrm{LVR})$ uses the genuine $\mathrm{LVR}$, though grouped in ranges of 10 percentage points width. Each such range is represented by its mid-value.

(e) Deviance is a measure of goodness of fit, related to the log likelihood ratio of the model. A lower deviance implies a better fit.

(f) The variables Area $k$ and AREA $m$ have already been described as $0-1$ indicator variables. The variables listed subsequently in the table are also of the $0-1$ indicator type, taking the value 1 if the loan is subject to the risk variable displayed, 0 otherwise. 
By (6.8) and (8.1), the model is multivariate Poisson with multiplicative structure of the mean. GLIM fits this by maximum likelihood. Note that the logarithmic form of (8.1) is no more than a convenience of expression. It could equally have been written in its unlogged (multiplicative) form. In particular, (8.1) does not imply that the observations $N(i, j)$ (many of which are zero) are to logged.

For the interpretation of this table, special reference should be made to geographic area of the mortgaged property. On the strength of the chart of Section 5.1, a number of areas, seemingly similar in claim frequency and/or physically contiguous, were aggregated. The areas at this initial level of aggregation were denoted by "Area $k$ ". These were $0-1$ variables, taking the value 1 if the property lay in the relevant area, 0 otherwise.

Regression 1 in the table indicated that further aggregation was possible. The new variables resulting from this aggregation were denoted by "AREA $m$ ", and were 0-1 variables, each of which consisted of the sum of the relevant variables Area $k$. The key to the two aggregations is as shown in the previous table but one.

It may be noted that the trial regressions included alternative versions of (8.1) in which the terms dependent on LVR and HPI were replaced by their respective unlogged forms, as discussed at the end of Section 6.2. These alternatives were, however, inferior to (8.1) in terms of fit.

Regression 7 provided the best fit of model to data, and was adopted as the final model. This final model, expressed in non-symbolic form, was as follows:

$\begin{array}{ll}\begin{array}{l}\text { CLAIM FREQUENCY }= \\ \text { (per 1000 advances) }\end{array} & 2.624(t+1 / 2)^{4.505} \exp (-0.8536 t) \\ \text { IN DEVELOPMENT YEAR } t & \times \\ & (\text { LVR })^{8.413} \\ & \div \\ & {\left[(\text { HOME AFFORDABILITY FACTOR })^{2.158}\right.} \\ & \times \\ & \left.(\text { PROPERTY GROWTH FACTOR })^{5.658}\right] \\ & \times \quad \begin{array}{l}1 \text { if AREA 1 } \\ 1.670 \text { if AREA } 2 \\ 2.404 \text { if AREA } 3 \\ 0.0007 \text { if AREA } 4\end{array}\end{array}$

where

HOME AFFORDABILITY FACTOR and PROPERTY GROWTH FACTOR are the ratios involving $H$ and $R$ respectively in (8.1).

The formula in the box indicates that claim frequency:

(a) moves sharply upward with increasing LVR; 
(b) moves sharply downward as property values or disposable incomes after mortgage instalments increase;

(c) varies significantly by geographic area, exhibiting a particularly low value in the Wollongong district.

Because of correlations of the type discussed at the end of Section 5.1, not all of the risk variables exhibited a significant effect on claim frequency.

\subsection{Average claim size}

The form of the model was suggested in Section 7 as the following:

$$
Q(i, j)=a+b H(i+j) / H(i)+\text { error term, }
$$

where approximately

$$
\text { error term } \sim N\left(0, \sigma^{2}\right) .
$$

This model appears unnatural to the extent that the normal error term would permit claim sizes to be negative. This would be avoided by the inclusion of an error term which was by nature positive. An example would be a lognormal error term, as would be incorporated in an alternative model of the form:

$$
\log Q(i, j)=\log a+b \log [H(i+j) / H(i)]+\text { error term, }
$$

where

$$
\text { error term } \sim N\left(0, \sigma^{2}\right) .
$$

Equivalently,

$$
Q(i, j)=a[H(i+j) / H(i)]^{b} \times \text { error term },
$$

where

$$
\text { error term }=\text { lognormal }\left(0, \sigma^{2}\right) .
$$

Note that both forms (7.2) and (8.5) accommodate the theoretical form (7.1).

Ordinary regression produced the following two alternative models.

\begin{tabular}{ccc}
\hline Parameter & Unlogged model (a) & Logged model (b) \\
\hline$a$ & 0.1622 & 0.1555 \\
$b$ & 0.0494 & 0.3083 \\
$\sigma^{2}$ & 0.0257 & 0.8676
\end{tabular}

\footnotetext{
(a) This is the model described by (7.2) and (7.3). Of the 425 observed claim ratios, 2 large values have been excluded as outliers.

(b) This is the model described by (8.3) and (8.4)
} 
In fact, neither of the two models considered in the preceding table produced an ideal fit to the data. Their respective residuals are tabulated in the following table.

\begin{tabular}{|c|c|c|c|}
\hline \multirow{2}{*}{\multicolumn{2}{|c|}{$\begin{array}{l}\text { Values of standardized } \\
\text { residuals }\end{array}$}} & \multicolumn{2}{|c|}{ Relative frequency of standardized residual in } \\
\hline & & Unlogged model & Logged model \\
\hline & & $\%$ & $\%$ \\
\hline less than & -3 & 0 & 1 \\
\hline-3 to & -2 & 0 & 3 \\
\hline-2 to & -1 & 12 & 8 \\
\hline-1 to & 0 & 47 & 32 \\
\hline to & 1 & 24 & 44 \\
\hline to & 2 & 10 & 12 \\
\hline 2 to & 3 & 5 & 0 \\
\hline more than & 3 & 1 & 0 \\
\hline \multicolumn{2}{|l|}{ Total } & 100 & 100 \\
\hline
\end{tabular}

These two tabulations of standardized residuals are very much reflections of each other about the origin. While the unlogged model is somewhat skewed to the right, the logged model is about equally skewed to the left. This suggests that the correct model lies somewhere between normal and log normal. Such a model might be of the form (7.2), but with the error term strictly positive and skewed to the right but less so than log normal.

Note that the fitted values of claim ratios, according to the two alternative models, are :

$$
\begin{aligned}
E Q(i, j) & =a+b H(i+j) / H(i) \text { for unlogged model; } \\
& =a[H(i+j) / H(i)]^{b} \exp \left(1 / 2 \sigma^{2}\right) \text { for logged model. }
\end{aligned}
$$

In the event, (8.8) produced a rather heavy upward bias, about $18 \%$ in total, in fitted values of claim amount relative to observed amounts. The form of this comparison was exactly as reported in Section 9.2, but with the unlogged model used there replaced by the logged.

This result appears to indicate that the exponential scaling factor in (8.8) is not robust against the non-normality in the error term of (8.4), as was demonstrated in the above table of standarized residuals.

On the other hand, Section 9.2 indicates that the unlogged model provides an adequate fit, and accordingly it was adopted.

\section{MODEL VERIFICATION}

\subsection{Claim frequency}

The model adopted in Section 8.1 has been used to compute standardized residuals according to several variables. The resulting residual plots appear 
below. Note that each residual relates to the aggregation of all experience at the value of the independent variable displayed. For example, the first residual in the first plot may be obtained from the second table of the present sub-section as:

$$
(8-6) / \sqrt{6}=0.8
$$

A plot of the residuals of all cells (taken over all explanatory variables) would not be helpful since the great majority of cells contain very small expectations.
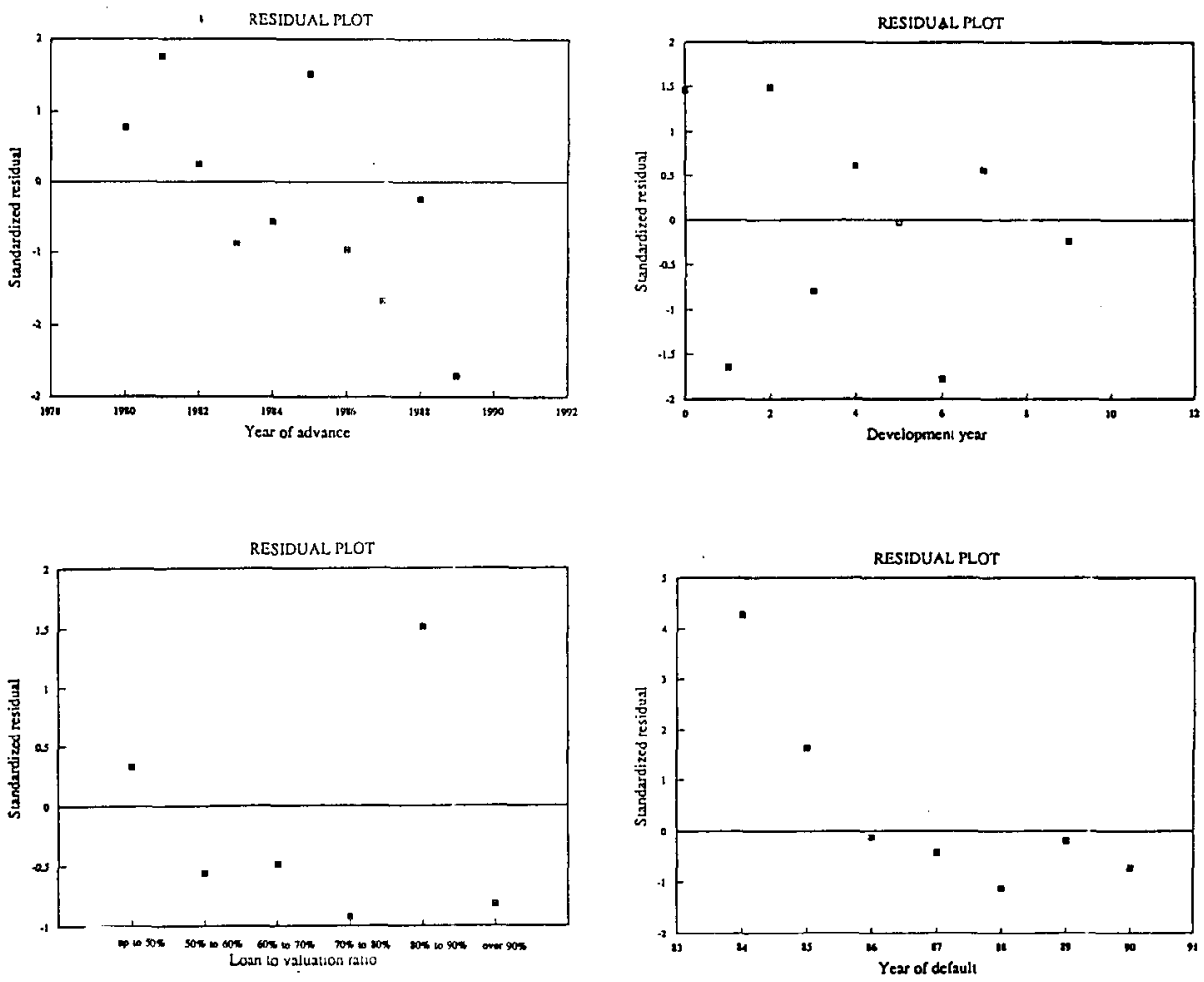

These plots appear generally satisfactory in terms of magnitude, with the exception of year of default 1984. This one anomaly, in the relatively distant past, involves relatively few claims (see first table below) and is insufficient to invalidate the model.

The plot against year of advance contains a downward trend. If included in the model, year of advance appears as a highly significant explanatory variable; other things equal, claim frequency declines by $29 \%$ as between each year of advance and the next. Naturally, the effects of the other explanatory variables, particularly those which are time dependent, change.

While this model provides a superior fit to the data, the abstract nature of the year of advance effect is problematic. It might be interpreted as a factor 
representing improvement in underwriting. However, in this case, the total improvement over the decade of underwriting would be almost $97 \%$, which might strain credulity.

It seems more likely that year of advance is acting as a proxy for some other unidentified explanatory variable(s). When this variable is omitted from the model, its effect is largely captured by the other explanatory variables.

Moreover, an examination of the fitted numbers of claims (using the model which omits year of advance effect) against the data suggests that the apparent trend in the residuals may not be particularly meaningful (see second table below).

The following table displays the actual and model numbers of claims underlying the above plot of standardized residuals by experience year.

\begin{tabular}{lcc}
\hline & Period & \multicolumn{2}{c}{ Number of claims emerging } \\
\cline { 2 - 3 } & Actual & Model \\
\hline 1984 (7 months) & 28 & 13 \\
1985 & 32 & 24 \\
1986 & 53 & 54 \\
1987 & 168 & 174 \\
1988 & 103 & 115 \\
1989 & 21 & 22 \\
1990 & 20 & 24 \\
\hline Total & 425 & 425 \\
\hline
\end{tabular}

The table illustrates the close agreement between actual and model numbers of claims for all experience years except 1984, despite the extreme fluctuations in numbers of claims.

More detailed information is given by the following table which tabulates experience and model simultaneously by year of advance and development year, and from which the above table may be derived.

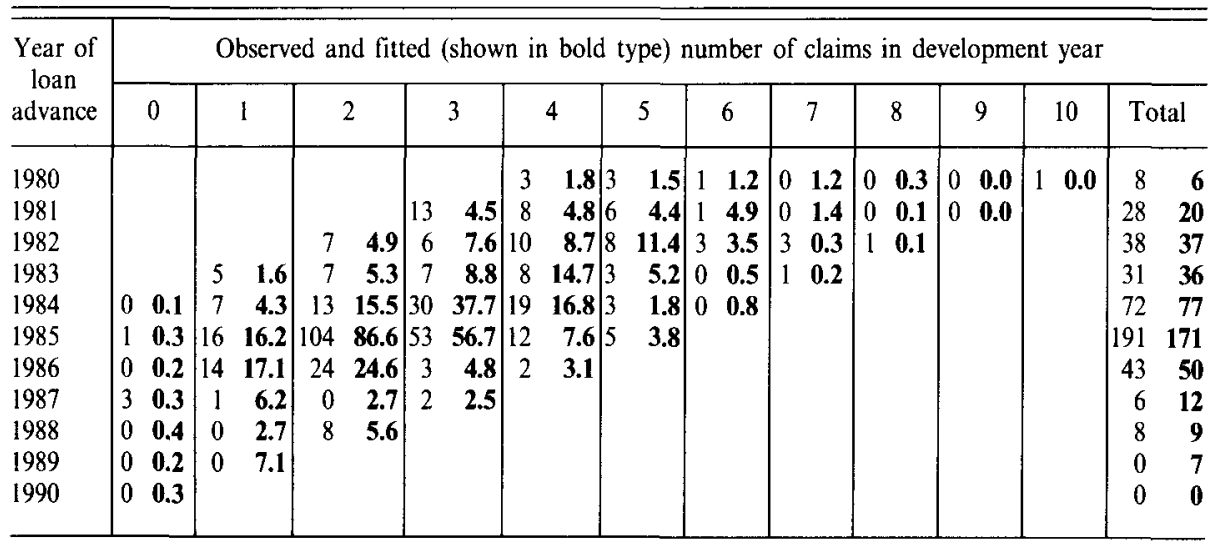


The following table presents these results in the same format as in Section 2, enabling comparison of the present set of results with those from the separation method.

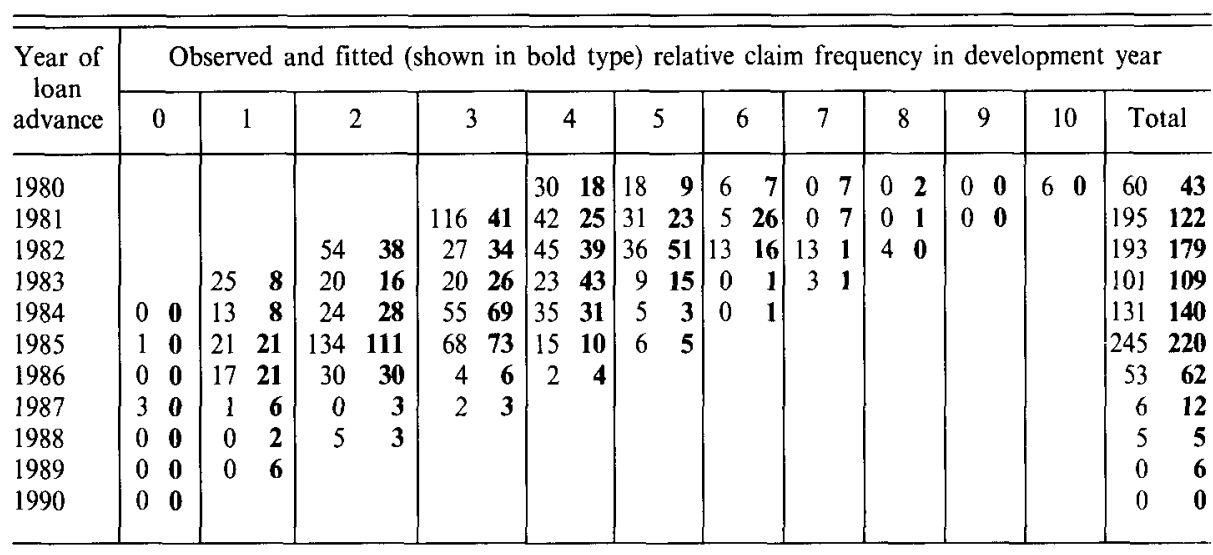

\subsection{Average claim ratio}

For each claim in the experience, a fitted value of its claim ratio was calculated according to (8.7) using the values of $a$ and $b$ tabulated in Section 8.2. Each of these claim ratios was multiplied by the associated amount of its loan, to produce a fitted claim size.

Observed and fitted claim sizes were then summarized in 2-way tabulations by year of advance and development year. These tabulations are displayed in Appendix E, and reduced to their corresponding 1-way tabulations below.

\begin{tabular}{|c|c|c|c|c|c|c|c|}
\hline \multirow[b]{2}{*}{$\begin{array}{c}\text { Year of } \\
\text { advance }\end{array}$} & \multicolumn{3}{|c|}{ Amount of claims } & \multirow[b]{2}{*}{$\begin{array}{c}\text { Development } \\
\text { year }\end{array}$} & \multicolumn{3}{|c|}{ Amount of claims } \\
\hline & Observed & Fitted & $\begin{array}{c}\text { Ratio: } \\
\text { Observed } \\
\frac{\text { fitted }}{}\end{array}$ & & Observed & Fitted & $\begin{array}{c}\text { Ratio: } \\
\text { Observed } \\
\frac{\text { fitted }}{}\end{array}$ \\
\hline & $\$ 000$ & $\$ 000$ & $\%$ & & $\$ 000$ & $\$ 000$ & $\%$ \\
\hline 1980 & 51 & 70 & 73 & 0 & 32 & 46 & 70 \\
\hline 1981 & 294 & 312 & 94 & 1 & 425 & 471 & 90 \\
\hline 1982 & 398 & 374 & 106 & 2 & 1750 & 1844 & 95 \\
\hline 1983 & 354 & 323 & 110 & 3 & 1051 & 1133 & 93 \\
\hline 1984 & 632 & 642 & 98 & 4 & 674 & 642 & 105 \\
\hline 1985 & 1931 & 2063 & 94 & 5 & 321 & 301 & 107 \\
\hline 1986 & 425 & 472 & 90 & 6 & 47 & 38 & 124 \\
\hline 1987 & 46 & 69 & 67 & 7 & 31 & 35 & 88 \\
\hline 1988 & 259 & 222 & 117 & 8 & 56 & 28 & 199 \\
\hline 1989 & 0 & 0 & & 9 & 0 & 0 & \\
\hline 1990 & 0 & 0 & & 10 & 1 & 7 & 14 \\
\hline Total & 4388 & 4545 & 97 & & 4388 & 4545 & 97 \\
\hline
\end{tabular}


It should be particularly noted that the fitted amounts of claims, according to the above description are conditional upon the observed numbers of claims. This is a proper approach to examination of the fit of the average claim size model. Agreement between model and data appears satisfactory.

It is useful to carry out some check that the common dependence of the claim frequency and claim size models on the HPI does not lead to unwanted correlation between the two. That this does not in fact occur is indicated by the following scatter plot of the observed fitted ratios of average claim size against a similar ratio for number of claims.

Each point represents a particular combination of year of advance and development year. To give a simple indication of the significance of the plotted points, they are divided into "large cells" and "small cells". The former are those cells containing a fitted number of claims in excess of 5; otherwise the cell is "small".

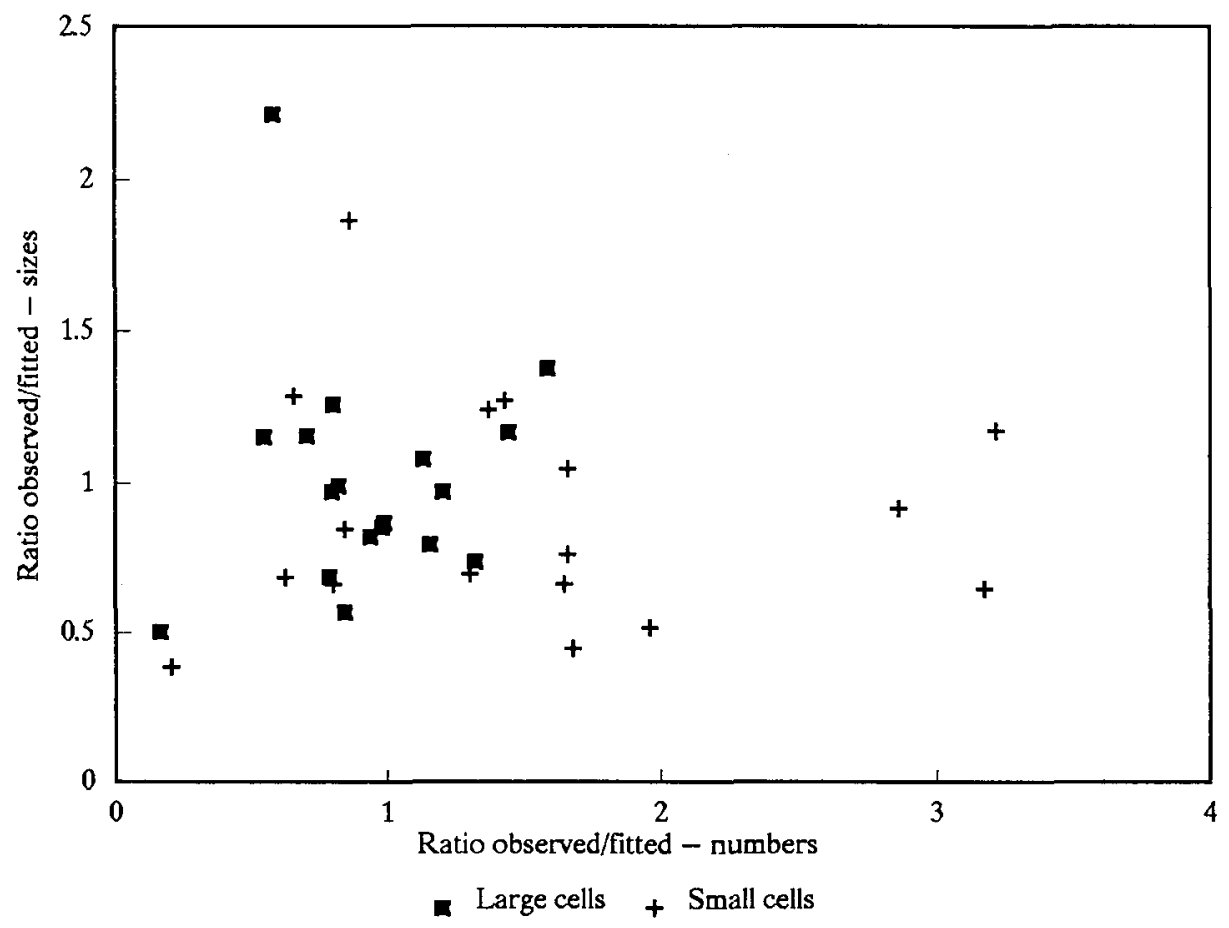

\subsection{Loan sizes associated with claims}

While Section 9.2 models the claim size which will arise from a particular loan size if a claim occurs, it provides no indication of which loan sizes are likely to lead to claims.

There is no particular reason to believe that the sizes of loans associated with claims will be representative of the entire portfolio of loans advanced. Indeed, 
the table below indicates that, on average, it is the larger loans that lead to claims.

Care is needed here, however, as the model of claim frequency in Section 9.1 conditions on LVR and other risk factors, for which average loan sizes may differ from the portfolio average, and so without further analysis it is not clear to what extent the inclusion of these factors in the model will effectively select average loan sizes above the portfolio average. This question is also examined in the following table.

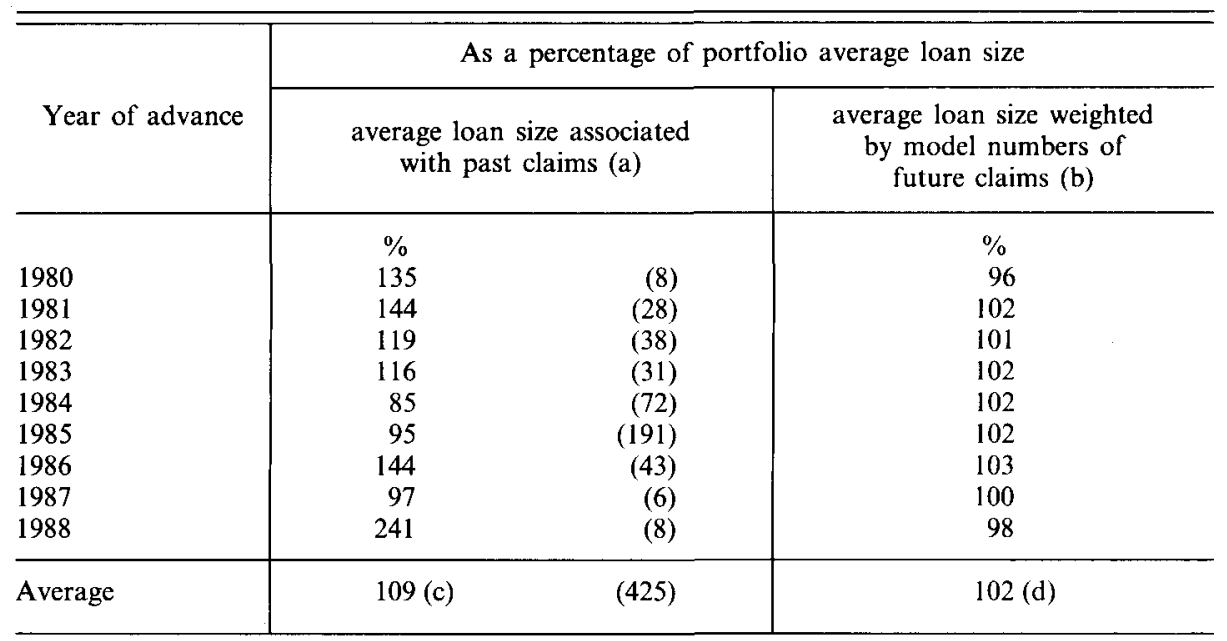

(a) The numbers of claims on which the ratios are based are shown in parenthesis. For each year of advance, the average size of loans associated with recorded ciaims has been calculated and related to the portfolio average (for that year of advance).

(b) For each combination of year of advance and risk variables, the average loan advanced and model claim frequency (according to the model of Section 8.1) are calculated. The average loan advanced, weighted by model claim frequency, is then calculated for each year of advance.

(c) Average of the entries in the column, weighted by numbers of claims shown in parenthesis.

(d) Unweighted average of the entries in the column.

The table suggests that the average loan size associated with claims of a particular cell for a particular year of advance is about $7 \%$ higher than the overall average loan size for the cell.

Thus, a forecast of future claim amount for a particular cell of development year $j$ of year of advance $i$ would be computed as :

$1.07 \times$ average loan size in year of advance $i$

$$
\times \hat{N}(i, j) \hat{Q}(i, j) \text {, }
$$

where $\hat{N}(i, j), \hat{Q}(i, j)$ are estimates of $N(i, j)$ and $Q(i, j)$ from Sections 9.1 and 9.2 .

An alternative approach to the above would be to include loan size as an explanatory variable in the claim frequency model of Section 8.1. This might be 
awkward in practice, however, because it would increase very considerably the number of data cells entering into the regressions of Section 8.1.

\section{CONCLUSION}

Section 8 fits models to the claim frequency and claim ratio in the mortgage insurance portfolio examined. Section 9 verifies that these models provide a reasonable fit to the data.

The models therefore can be, and indeed have been, used to estimate the liability for claims still to emerge in respect of past years of loan advance. In order to carry out this estimation, one needs to project future values of the HAI and HPI. This in turn requires projection of incomes, tax rates, mortgage interest rates and growth in property values. Projections such as these are, problems of substance in their own right, but are beyond the scope of the present paper.

\section{ACKNOWLEDGEMENT}

I should like to acknowledge the computing assistance provided by $\mathrm{Mr} \mathrm{A}$. J. Greenfield in the preparation of this paper.

\section{APPENDIX A}

\section{DEPENDENCE OF CLAIM FREQUENCY ON HOME AFFORDABILITY INDEX}

Let $X$ denote the random variable representing the proportion of an individual's income required for tax, consumption and mortgage instalment. Assume this variable to be Pareto distributed, i.e. with p.d.f.:

$$
f(x)=k x^{-\alpha-1}, k \text { const. }
$$

The borrower will experience financial difficulties if $X \geq 1$, which occurs with probability:

$$
P[X \geq 1]=k x^{-\alpha} /\left.\alpha\right|_{x=1} .
$$

Now, suppose that $X$ shifts by a factor of $c$ to $X^{\prime}=c X$. Then the probability (A.2) shifts to

$$
P\left[X^{\prime} \geq 1\right]=P[X \geq 1 / c]=k x^{-\alpha} /\left.\alpha\right|_{x=1 / c} .
$$

Comparison of (A.2) and (A.3) shows that the probability (A.2) has shifted by a factor of $c^{\alpha}$. Now note that the scale shift of $X$ to $c X$ must shift the mean of $X$ by a factor of $c$ :

$$
E\left[X^{\prime}\right]=c E[X]
$$

Let

$$
Y=1-X
$$


and note that

$$
E[Y] \propto \text { HAI. }
$$

Then the factor by which HAI changes when $X$ changes to $X^{\prime}$ is:

$$
\begin{aligned}
& R=\left\{1-E\left[X^{\prime}\right]\right\} /\{1-E[X]\} \\
& =(1-c \mu) /(1-\mu),
\end{aligned}
$$

where

$$
\mu=E[X]
$$

Inversion of (A.6) yields :

$$
c=[1-R(1-\mu)] / \mu .
$$

Thus, the shift in HAI by a factor of $R$ causes the frequency with which borrowers experience difficulties to shift by a factor of:

$$
c^{\alpha}=\{[1-R(1-\mu)] / \mu\}^{\alpha} .
$$

Now, it is convenient to analyse $\log$ (claim frequency), which will depend on $\log$ (frequency of borrower's difficulties), and (A.8) shows that this latter will depend on an additive term of:

$$
\begin{aligned}
\log c^{\alpha} & =\alpha \log \{[1-R(1-\mu)] / \mu\} \\
& \sim-\alpha R(1-\mu)+\text { const. }
\end{aligned}
$$

for small values of $(1-\mu) R$.

Thus, to first approximation, the model of expected log (claim frequency) should include a linear term in $R$, the ratio by which HAI has changed since advance of the loan(s) in question.

\section{APPENDIX B}

\section{DEPENDENCE OF CLAIM FREQUENCY ON HOUSING PRICE INDEX, LVR AND DEVELOPMENT YEAR}

Consider a loan taken at time $t=0$. Let $V(t)$ be the value of the associated property at time $t$, and $P(t)$ the amount of principal then outstanding. Then

$$
\begin{aligned}
& V(t)=V(0)[H(t) / H(0)], \\
& P(t)=P(0) f(t),
\end{aligned}
$$

where

$$
\begin{aligned}
& H(t)=\text { HPI at time } t \\
& f(t)=\text { proportion of principal still to be repaid at time } t
\end{aligned}
$$

By (B.1) and (B.2),

$$
P(t) / V(t)=L f(t) H(0) / H(t),
$$


where

$$
L=P(0) / V(0)=\text { loan to valuation ratio } .
$$

Suppose that the borrower has encountered financial difficulties at some time $s<t$. At time $t$ sale of the property is forced. At that point, the debt in respect of the loan will be $P(t) \alpha(t)$, where

$\alpha(t)=$ a random variable representing the factor by which outstanding principal has been enlarged by arrears of principal and interest and any other costs.

Similarly, the net proceeds of the sale of the property will be $V(t) \beta(t)$, where

$\beta(t)=$ a random variable iepresenting the factor by which the property value has been reduced by the forced nature of the sale and the associated expenses.

Then the ratio of outstanding debt to sale proceeds is:

$$
X(t)=\gamma(t) P(t) / V(t),
$$

where

$$
\gamma(t)=\alpha(t) / \beta(t)
$$

By (B.3) and (B.5),

$$
X(t)=L[H(t) / H(0)]^{-1} f(t) \gamma(t) .
$$

A claim will occur if $X(t)>1$, i.e. if

$$
\gamma(t)>[H(t) / H(0)][L f(t)]^{-1} .
$$

Now suppose that $\gamma(t)$ is Pareto distributed with d.f.

$$
F(\gamma)=1-(\gamma / a)^{-v}, \quad \gamma>a,
$$

assumed independent of $t$. Then, by (B.8), the probability of occurrence of a claim is:

$$
P[X(t)>1]=\left\{a f(t) L[H(t) / H(0)]^{-1}\right\}^{v} .
$$

Thus, expected claim frequency varies as a power of $L[H(t) / H(0)]^{-1}$. Note also that claim frequency for policies of a particular term $n$ varies over development years $t$ by a factor of

$$
[f(t)]^{v} \quad \propto \quad\left[a_{n-t}\right]^{v},
$$

which has the shape illustrated by the solid line in the following diagram.

However, note the above assumption that the distribution of the factor $\gamma(t)$ is independent of $t$. While perhaps largely true, it will break down as $t \rightarrow 0$ as the screening procedures of the lender force claim frequency toward zero. Hence, the curve (B.11) of frequency over development year will be modified for small $t$ in the manner indicated by the broken line in the diagram. 


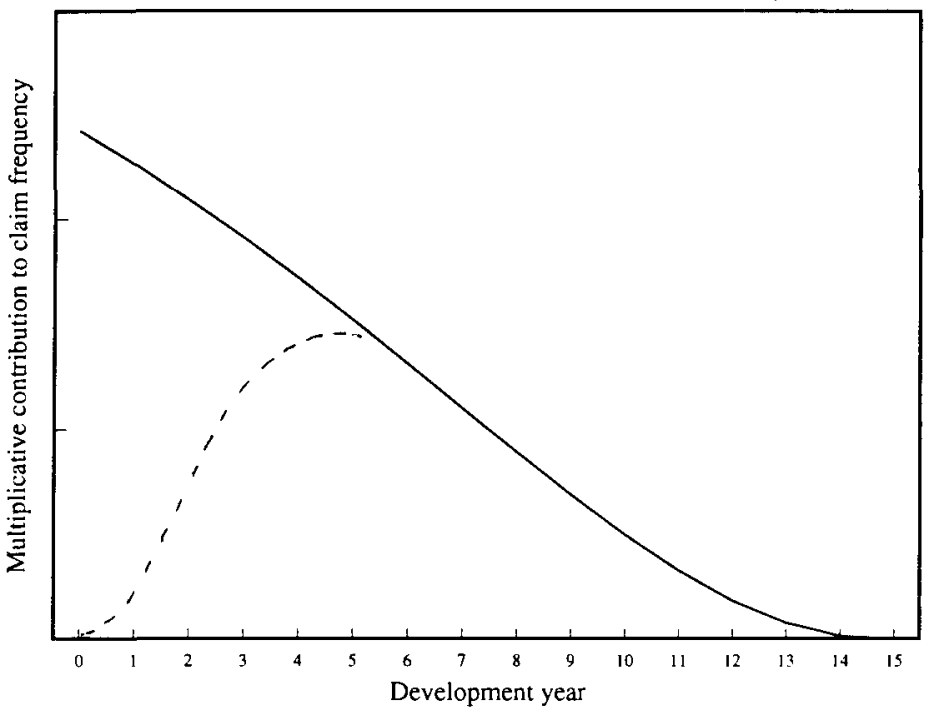

When allowance is made for the variety of original terms $n$, the dependence of claim frequency on development year is seen to be represented by a weighted average of curves of the type illustrated in the diagram.

\section{APPENDIX C}

\section{DEPENDENCE OF AVERAGE CLAIM SIZE ON HOUSING PRICE INDEX}

As noted just prior to (B.8), the financial difficulties of a borrower will lead to a claim if $X(t)$, as defined there, exceeds 1 . In fact, by the same argument as led to that result, the amount of the claim will be

$$
\begin{aligned}
\mathrm{A}(t) & =\alpha(t) P(t)-\beta(t) V(t) \\
& =\beta(t) V(t)[X(t)-1] .
\end{aligned}
$$

Note that $\beta(t)$ and $\gamma(t)$ (and hence $X(t)$ ) will not be independent, even if $\alpha(t)$ and $\beta(t)$ are. For general random variables $Y$ and $Z$, let $\mu_{Y}$ and $\mu_{Z}$ denote their means, $v_{Y}$ and $v_{Z}$ their coefficients of variation, and $\rho_{Y Z}$ their correlation. It is straightforward to demonstrate that:

$$
E[Y Z]=\mu_{Y} \mu_{Z}\left(1+\rho_{Y Z} v_{Y} v_{Z}\right)
$$

By (C.1) and (C.2),

$$
E[A(t)]=V(t) E[X(t)-1]_{+} \mu_{\beta}\left(1+\rho_{\beta X} v_{\beta} v_{X}\right),
$$

where $E[Y]_{+}$denotes $E[Y \mid Y>0]$.

Now, by (B.5)

$$
E[X(t)-1]_{+}=E[\gamma(t)-V(t) / P(t)]_{+} P(t) / V(t) .
$$


By the Pareto assumption (B.9),

(C.5) $\quad E[\gamma(t)-V(t) / P(t)]_{+}=[V(t) / P(t)] v /(v-1)$, whence (C.3) and (C.4) yield :

(C.6)

$$
\begin{aligned}
E[A(t)]= & V(t) \mu_{\beta}\left(1+\rho_{\beta X} v_{\beta} v_{X}\right) v /(v-1) \\
& \propto V(0) H(t) / H(0) \quad[\text { by (B. } 1)]
\end{aligned}
$$

if $\mu_{\beta}, v_{\beta}, v_{X}$ and $\rho_{\beta X}$ are the assumed independent of $t$.

Thus, the expected average claim size is directly proportional to property values, all other things equal. This has the interesting effect of causing average claim size in respect of a group of identical policies usually to increase with development year even though outstanding principal is decreasing.

\section{APPENDIX D}

\section{EXPLORATORY ANALYSIS OF CLAIM SIZE}

\section{D1. Variation of claim ratio with loan to valuation ratio}

\begin{tabular}{l|c|c|c|c|c}
\hline \multirow{2}{*}{$\begin{array}{c}\text { Loan to } \\
\text { valuation } \\
\text { ratio }\end{array}$} & $\begin{array}{c}\text { Number } \\
\text { of claims }\end{array}$ & $\begin{array}{c}\text { Claim to loan ratio } \\
\text { Sample } \\
\text { mean }\end{array}$ & $\begin{array}{c}\text { Sample } \\
\text { standard } \\
\text { deviation }\end{array}$ & Lower & \multicolumn{2}{c}{ Upper } \\
\cline { 3 - 6 } & 1 & $55.8 \%$ & & & \\
up to $50 \%$ & 1 & $56.9 \%$ & & & \\
50 to $60 \%$ & 8 & $23.3 \%$ & $13.7 \%$ & $11.8 \%$ & $34.8 \%$ \\
60 to $70 \%$ & 189 & $23.9 \%$ & $19.2 \%$ & $17.4 \%$ & $30.4 \%$ \\
70 to $80 \%$ & 191 & $22.9 \%$ & $18.4 \%$ & $20.3 \%$ & $25.6 \%$ \\
80 to $90 \%$ & $23.5 \%$ & $15.6 \%$ & $21.3 \%$ & $25.7 \%$ \\
over $90 \%$ & $36 \%$ & & & &
\end{tabular}

(a) These are the symetric $t$-distribution confidence limits. Where the sample size is less than 2 , the confidence limits do not exist.

D2. Variation of claim ratio with term

\begin{tabular}{l|c|c|c|c|c}
\hline \multirow{2}{*}{ Term } & \multirow{2}{*}{$\begin{array}{c}\text { Number } \\
\text { of claims }\end{array}$} & \begin{tabular}{c} 
Claim to loan ratio \\
Sample \\
\cline { 3 - 5 }
\end{tabular} & $\begin{array}{c}\text { Sample } \\
\text { standard } \\
\text { deviation }\end{array}$ & Lower & \multicolumn{2}{|c}{ U5\% confidence limits (a) } \\
\hline months & & & & & \\
60 to 119 & 16 & $36.4 \%$ & $14.1 \%$ & $1.3 \%$ & $71.4 \%$ \\
120 to 179 & 55 & $34.8 \%$ & $29.8 \%$ & $18.9 \%$ & $50.7 \%$ \\
180 to 239 & 352 & $28.4 \%$ & $20.2 \%$ & $22.9 \%$ & $33.9 \%$ \\
240 \& more & & $15.6 \%$ & $20.4 \%$ & $23.7 \%$ \\
\hline
\end{tabular}

(a) See Appendix Dl. 
D3. Variation of claim ratio with area

\begin{tabular}{|c|c|c|c|c|c|}
\hline \multirow[b]{2}{*}{ Area } & \multirow[b]{2}{*}{$\begin{array}{l}\text { Number } \\
\text { of claims }\end{array}$} & \multicolumn{2}{|c|}{ Claim to loan ratio } & \multicolumn{2}{|c|}{$95 \%$ confidence limits (a) } \\
\hline & & $\begin{array}{c}\text { Sample } \\
\text { mean }\end{array}$ & $\begin{array}{c}\text { Sample } \\
\text { standard } \\
\text { deviation }\end{array}$ & Lower & Upper \\
\hline $\mathbf{M 1 ,} \mathbf{M 4}$ & 29 & $16.5 \%$ & $11.7 \%$ & $12.0 \%$ & $20.9 \%$ \\
\hline M2 & 63 & $21.2 \%$ & $15.0 \%$ & $17.5 \%$ & $25.0 \%$ \\
\hline M3 & 77 & $16.5 \%$ & $12.6 \%$ & $13.7 \%$ & $19.4 \%$ \\
\hline M5 & 5 & $25.8 \%$ & $14.8 \%$ & $7.5 \%$ & $44.1 \%$ \\
\hline Canberra & 4 & $23.1 \%$ & $13.0 \%$ & $2.4 \%$ & $43.8 \%$ \\
\hline Coastal & 100 & $24.6 \%$ & $18.2 \%$ & $21.0 \%$ & $28.2 \%$ \\
\hline Newcastle & 32 & $31.7 \%$ & $17.2 \%$ & $25.6 \%$ & $37.9 \%$ \\
\hline Wollongong & 0 & & & & \\
\hline Other & 116 & $27.5 \%$ & $19.4 \%$ & $23.9 \%$ & $31.1 \%$ \\
\hline
\end{tabular}

(a) See Appendix D1.

\section{D4. Commentary}

All pairs of confidence limits in Appendices D1 to D3 straddle the overall mean of $23.4 \%$ except in four cases. All four of these cases relate to area of residence, and are found in Appendix D3.

\section{APPENDIX E}

\section{COMPARISON OF OBSERVED AND FITTED CLAIM AMOUNTS}

The following are the amounts of claim observed in respect of each combination of year of advance and development year.

\begin{tabular}{|c|c|c|c|c|c|c|c|c|c|c|c|}
\hline \multirow{2}{*}{$\begin{array}{l}\text { Year of } \\
\text { advance }\end{array}$} & \multicolumn{11}{|c|}{ Amount of claims observed in development year } \\
\hline & 0 & 1 & 2 & 3 & 4 & 5 & 6 & 7 & 8 & 9 & 10 \\
\hline 1980 & $\$$ & $\$$ & $\$$ & $\$$ & $\begin{array}{c}\$ \\
28522\end{array}$ & $\begin{array}{c}\$ \\
13349\end{array}$ & $\underset{7873}{\$}$ & $\$_{0}$ & $\$_{0}$ & $\begin{array}{l}\$ \\
0\end{array}$ & $\underset{1009}{\$}$ \\
\hline 1981 & & & & 115151 & 69711 & 105156 & 3724 & & & 0 & \\
\hline 1982 & & & 71488 & 29799 & 102851 & 81026 & 35484 & 20827 & 56169 & & \\
\hline 1983 & & 60085 & 71469 & 61801 & 85959 & 64416 & 0 & 10110 & & & \\
\hline 1984 & 0 & 45337 & 68811 & 325411 & 180820 & 11766 & 0 & & & & \\
\hline 1985 & 9591 & 161743 & 1060021 & 474840 & 179612 & 44976 & & & & & \\
\hline 1986 & 0 & 150351 & 219581 & 28174 & 26638 & & & & & & \\
\hline 1987 & 22882 & 7054 & & 15810 & & & & & & & \\
\hline 1988 & 0 & 0 & 258976 & & & & & & & & \\
\hline 1989 & 0 & 0 & & & & & & & & & \\
\hline 1990 & 0 & & & & & & & & & & \\
\hline
\end{tabular}


The following are the amounts of claims fitted to each combination of year of advance and development year by the procedure described in Section 9.2.

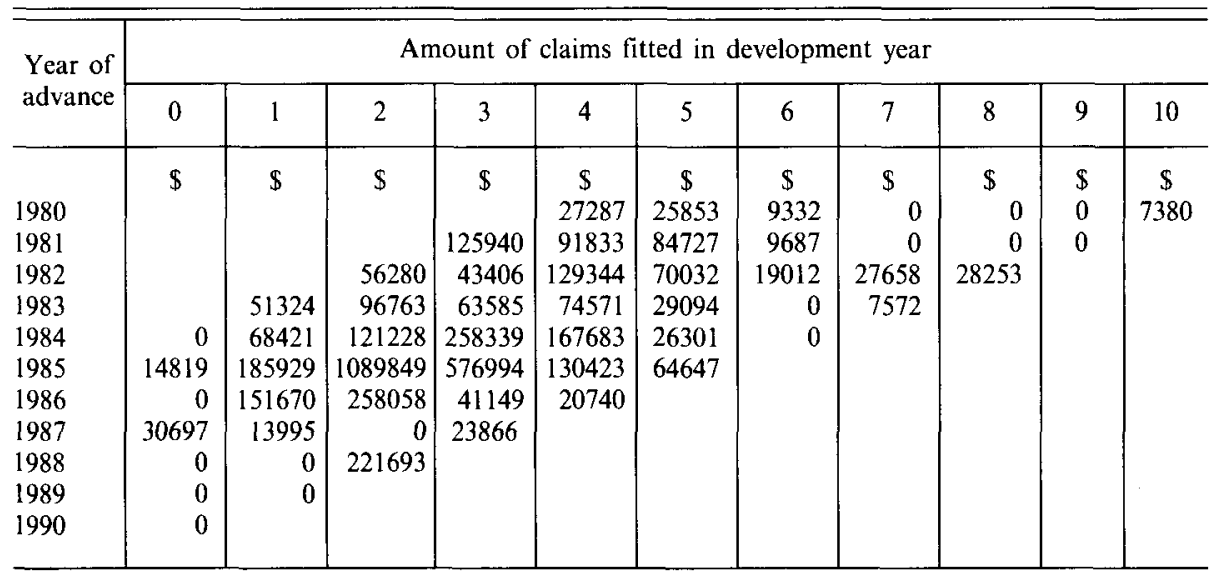

Each cell in this table is of the form:

actual number of claims

$\times$

fitted average claim size.

Hence comparison of the table with the previous one examines only variation of experience from model amounts of claim.

An alternative version of the preceding table consists of cells of the form:

fitted number of claims

$\times$

fitted average claim size.

This table is as follows.

\begin{tabular}{|c|c|c|c|c|c|c|c|c|c|c|c|}
\hline \multirow{2}{*}{$\begin{array}{l}\text { Year of } \\
\text { advance }\end{array}$} & \multicolumn{11}{|c|}{ Amount of claims fitted in development year } \\
\hline & 0 & 1 & 2 & 3 & 4 & 5 & 6 & 7 & 8 & 9 & 10 \\
\hline 1980 & $\$$ & $\$$ & $\$$ & $\$$ & $\begin{array}{c}\$ \\
16472\end{array}$ & $\begin{array}{c}\$ \\
13202\end{array}$ & $\begin{array}{c}\$ \\
11077\end{array}$ & ${ }^{\$}$ & ${ }_{0}^{\$}$ & $\begin{array}{l}\$ \\
0\end{array}$ & $\begin{array}{c}\$ \\
52\end{array}$ \\
\hline 1981 & & & & 44040 & 55444 & 61935 & 47805 & $\mathbf{0}$ & & $\mathbf{0}$ & \\
\hline 1982 & & & 39396 & 55278 & 111986 & 99883 & 22086 & 2637 & 2910 & & \\
\hline 1983 & & 15962 & 73512 & 80326 & 136558 & 50459 & 0 & 1408 & & & \\
\hline 1984 & $\mathbf{0}$ & 41551 & 144634 & 324560 & 148532 & 15693 & 0 & & & & \\
\hline 1985 & 4668 & 188718 & 907194 & 617384 & 82395 & 49662 & & & & & \\
\hline 1986 & & 185146 & 264079 & 66099 & 31805 & & & & & & \\
\hline 1987 & 3131 & 86881 & & 29785 & & & & & & & \\
\hline 1988 & 0 & 0 & 153966 & & & & & & & & \\
\hline 1989 & $\mathbf{0}$ & $\mathbf{0}$ & & & & & & & & & \\
\hline 1990 & 0 & & & & & & & & & & \\
\hline
\end{tabular}

For cells in which where are no claims observed, the procedure of Section 9.2 does not produce a fitted average claim size. These cells, indicated in bold, have been assigned a fitted amount of claims equal to zero. 


\section{APPENDIX F}

HOME AFFORDABILITY INDEX

\begin{tabular}{|c|c|c|c|c|c|c|c|c|c|}
\hline \multirow{3}{*}{$\begin{array}{c}\text { Year } \\
\text { (as at } \\
31 \text { De- } \\
\text { cember) }\end{array}$} & \multicolumn{3}{|c|}{ Economic indicators } & \multicolumn{6}{|c|}{ Household expenditure } \\
\hline & \multirow[b]{2}{*}{$\begin{array}{l}\text { Aver- } \\
\text { age } \\
\text { weekly } \\
\text { ear- } \\
\text { nings }\end{array}$} & \multirow[b]{2}{*}{$\begin{array}{l}\text { Con- } \\
\text { sumer } \\
\text { price } \\
\text { index }\end{array}$} & \multirow[b]{2}{*}{$\begin{array}{l}\text { Mort- } \\
\text { gage } \\
\text { interest } \\
\text { rates (a) }\end{array}$} & \multirow[b]{2}{*}{$\begin{array}{l}\text { Gross } \\
\text { house- } \\
\text { hold } \\
\text { income } \\
\text { (b) }\end{array}$} & \multirow[b]{2}{*}{$\begin{array}{l}\text { Tax } \\
\text { (b) }\end{array}$} & \multirow[b]{2}{*}{$\begin{array}{l}\text { Con- } \\
\text { sumer } \\
\text { expen- } \\
\text { diture } \\
\text { (b) }\end{array}$} & \multirow[b]{2}{*}{$\begin{array}{l}\text { Mort- } \\
\text { gage } \\
\text { instal- } \\
\text { ment } \\
\text { (b) }\end{array}$} & \multicolumn{2}{|c|}{ Residual income } \\
\hline & & & & & & & & Amount & $\begin{array}{l}\text { As per- } \\
\text { centage } \\
\text { of } \\
\text { gross } \\
\text { income }\end{array}$ \\
\hline & $\$$ & & p.a. & $\begin{array}{l}\$ \text { per } \\
\text { week }\end{array}$ & $\begin{array}{l}\$ \text { per } \\
\text { week }\end{array}$ & $\begin{array}{l}\$ \text { per } \\
\text { week }\end{array}$ & $\begin{array}{l}\$ \text { per } \\
\text { week }\end{array}$ & $\begin{array}{l}\$ \text { per } \\
\text { week }\end{array}$ & \\
\hline 1978 & 224.35 & 82.4 & $11.50 \%$ & 562.74 & 118.28 & 326.21 & 64.40 & 53.85 & $9.569 \%$ \\
\hline 1979 & 246.00 & 91.1 & $11.50 \%$ & 617.05 & 129.70 & 360.65 & 70.61 & 56.08 & $9.089 \%$ \\
\hline 1980 & 278.25 & 100.0 & $12.00 \%$ & 697.94 & 146.70 & 395.89 & 82.26 & 73.10 & $10.473 \%$ \\
\hline 1981 & 315.90 & 110.2 & $14.50 \%$ & 792.38 & 166.55 & 436.27 & 107.18 & 82.39 & $10.397 \%$ \\
\hline 1982 & 346.70 & 123.4 & $15.50 \%$ & 869.64 & 182.79 & 488.52 & 123.78 & 74.54 & $8.572 \%$ \\
\hline 1983 & 375.90 & 130.9 & $14.00 \%$ & 942.88 & 198.19 & 518.22 & 124.22 & 102.26 & $10.846 \%$ \\
\hline 1984 & 405.40 & 136.0 & $13.50 \%$ & 1016.88 & 213.74 & 538.41 & 130.41 & 134.33 & $13.210 \%$ \\
\hline 1985 & 428.20 & 147.5 & $15.00 \%$ & 1074.07 & 225.76 & 583.93 & 149.07 & 115.30 & $10.735 \%$ \\
\hline 1986 & 450.85 & 161.4 & $15.50 \%$ & 1130.88 & 237.70 & 638.96 & 160.96 & 93.25 & $8.246 \%$ \\
\hline 1987 & 477.70 & 173.7 & $14.50 \%$ & 1198.23 & 251.86 & 687.66 & 162.07 & 96.64 & $8.066 \%$ \\
\hline 1988 & 521.65 & 187.7 & $14.25 \%$ & 1308.47 & 275.03 & 743.08 & 174.68 & 115.68 & $8.841 \%$ \\
\hline 1989 & 560.75 & 203.0 & $17.25 \%$ & 1406.55 & 295.64 & 803.65 & 217.77 & 89.48 & $6.362 \%$ \\
\hline 1990 & 600.68 & 213.0 & $15.50 \%$ & 1506.69 & 316.69 & 843.24 & 214.46 & 132.30 & $8.781 \%$ \\
\hline
\end{tabular}

(a) The most common interest rates applying to loans in the mortgage insurance portfolio under analysis.

(b) These four columns were derived in a consistent manner from the HES, as described in Section 3.2 . 


\section{APPENDIX G}

\section{DATA}

The data described in Section 4.2 are summarized in the following table. This should be considered in conjunction with the qualification set out in the final paragraph of Section 4.2.

\begin{tabular}{|c|c|c|c|c|c|c|c|c|c|c|c|c|}
\hline \multirow{2}{*}{$\begin{array}{l}\text { Year of } \\
\text { advance }\end{array}$} & \multirow{2}{*}{$\begin{array}{l}\text { Number } \\
\text { of loans } \\
\text { advanced }\end{array}$} & \multicolumn{11}{|c|}{ Number of claims (a) recorded in development year } \\
\hline & & 0 & 1 & 2 & 3 & 4 & 5 & 6 & 7 & 8 & 9 & 10 \\
\hline 1980 & 1700 & & & & & 3 & 3 & 1 & 0 & 0 & 0 & 1 \\
\hline 1981 & 1917 & & & & 13 & 8 & 6 & 1 & 0 & 0 & 0 & \\
\hline 1982 & 2231 & & & 7 & 6 & 10 & 8 & 3 & 3 & 1 & & \\
\hline 1983 & 3426 & & 5 & 7 & 7 & 8 & 3 & 0 & 1 & & & \\
\hline 1984 & 5496 & 0 & 7 & 13 & 30 & 19 & 3 & 0 & & & & \\
\hline 1985 & 7787 & 1 & 16 & 104 & 53 & 12 & 5 & & & & & \\
\hline 1986 & 8077 & 0 & 14 & 24 & 3 & 2 & & & & & & \\
\hline 1987 & 9910 & 3 & 1 & 0 & 2 & & & & & & & \\
\hline 1988 & 17646 & 0 & 0 & 8 & & & & & & & & \\
\hline 1989 & 11878 & 0 & 0 & & & & & & & & & \\
\hline 1990 & 13614 & 0 & & & & & & & & & & \\
\hline
\end{tabular}

(a) Development year is defined as year of emergence of claim minus year of loan advance. Claims emerging in 1984 represent the experience of only 7 months. 